\title{
The Functions of Speculation in Economy: An Investigation on the New York Stock Exchange Crash (1929-39)
}

\author{
Hussin Salamon ${ }^{1}$, Mansoureh Ebrahimi ${ }^{1}$ \& Kamaruzaman Yusoff ${ }^{1}$ \\ ${ }^{1}$ Faculty of Islamic Civilization, Universiti Teknologi Malaysia, Johor Bahru, Johor, Malaysia \\ Correspondence: Mansoureh Ebrahimi, Faculty of Islamic Civilization, Universiti Teknologi Malaysia, 81310 \\ Johor Bahru, Johor, Malaysia. Tel: 60-755-57682; 60-14-220-1703. E-mail: mansoureh@utm.my
}

Received: July 8, 2013 Accepted: August 12, 2014 Online Published: September 29, 2014

doi:10.5539/ass.v10n19p129 URL: http://dx.doi.org/10.5539/ass.v10n19p129

\begin{abstract}
The importance of the role played by a stock market in the economic condition of a country is undeniable. An organized and stable stock market reflects an economic stability; progressive economic growth as well as reflecting the economic prosperity. In contrast, an unstable stock market indicates the vulnerable economical position of a country. The main aim of this article is to focus on the negative consequences of speculation and to discuss deeply on its role in financial crises. For this purpose, the crash of the New York Stock Exchange in 1929 will specifically be referred to because it was the world's greatest economic crash. Consequently, an unstable stock market has caused economic crashes not only for the country in which it occurs but also affects other countries because of interdependent economies. The best example of this situation was the World Great Depression which threatened the world economy in the 1930s.
\end{abstract}

Keywords: speculation, stock market, the New York stock exchange, the world great depression

\section{Introduction}

As the U.S. was the economic power after the First World War, the world economic condition was also based in one way or another on the economic prosperity of the U.S. However, when the U.S. economy went through the very real horror of a financial crash in 1929-1933, it did not only affect millions of small depositors in the U.S. (Coakley \& Harris, 1983, p. 69), but more importantly the whole world faced a crucial economic situation. The biggest contribution to the collapse of the economy of the U.S. in the tragedy of the 1930s was the crumbling down of the U.S. stock market, the New York Stock Exchange. Wall Street crashed and affected the world's economy, which was encountered more severely by small underdeveloped countries which based their economic prosperity on the export of raw materials. It can be clearly seen that countries which based their economic prosperity on primary sources were facing very low prices for their production, while manufacturing countries were encountering very high rates of unemployment (Hanson, 1977, p. 231).

The main factor that led to the crash of the New York Stock Exchange was the unstable prices of the stock traded. In a very short period, the traded prices of shares rocketed to their highest levels and unexpectedly began crashing down to earth within a very short time (Samuelson, 1958, pp. 426-427). The New York stock Exchange at that period fell by about 36 percent during the first stage of depression (1929) and further decreased by another 80 percent between 1930 and 1932 after stocks had recovered half of their losses from the first stage (Soros, 1994, p. 345). However, the worst period was in 1933 when within 3 years the U.S. national income sank by nearly one-half, capital investment plunged to the point where net investment was negative, one out of three laborers was forced to resign and the whole banking system collapsed (Ransom, 1982, p. 460).

The situation of the New York Stock Exchange at the time shortly before the collapse was psychotic. The buyers and investors, as well as the speculators, were going crazy, buying everything available from the market, making the prices of stocks increase rapidly. In contrast, when the price reached its zenith, while thousands of investors, especially small investors and speculators, were still crazed on buying anything left in the market, the real, big and smart speculators had already let go of their shares. They made a very handsome profit at the expense of those investors and small speculators (Teweles et al., 1965, p. 299). The small investors and speculators were being victimized by the havoc, and a chaotic situation prevailed in the New York Stock Exchange as a result of speculative activities done by the larger, smarter speculators. Millions of dollars was wasted in this economic tragedy of the early 20th century (Coakley \& Harris, 1983, p. 69). 
What was behind the irrational fluctuation of the stock market prices which ended with the Crash? The foremost reason according to economists, was the speculative activity which steered the whole market of the New York Stock Exchange at that time, and which consequently led to its downfall (Galbraith, 1969, p. 26). These activities led to the insane fluctuation of share prices. Within a few days, the prices of stocks and shares reached their highest point and then all of a sudden, the prices fell to their lowest level. The unchecked speculative activities made the New York Stock Exchange crumble down and the whole world was in one way or another, experiencing the agony of the worst ever U.S. economic condition. Since then, speculative activity in the stock market has been taken more into consideration and has been more seriously discussed. In the words of Galbraith "since 1929 we have erected numerous laws designed to make securities speculation more honest and it is hoped more readily restrained" (Galbraith, 1969, p. 28).

\section{The Multivalued Functions of Speculation}

There are a few functions that are undertaken by speculation and speculative judgment in the world of economics. The emergence of a speculative class as early as the 1850's (Emery, 1968, pp. 104-109), that was differentiated from the trading and producing body was something very significant in the economic world. This is because the class which was termed 'speculator' was always ready to take over any risk from the merchants by buying from them or by selling the commodity to them.

The complete transformation in trade that took place in the early 19th century demanded the existence of risks. The advancement of transportation and communication methods as well as technological achievement led to a drastic change in the market condition, from separated and independent local markets to a global market. While supply and demand in a local independent market would always play a prominent role as price regulators, which consequently lead to speculative judgment, it is not so in the new global market which needs more than supply and demand to make any speculative decision. Hence, to bear a speculative risk in the local market as part of their business is something usual and manageable to the merchant.

However, when the market changes and the knowledge of local conditions is inadequate to pass a speculative judgment, the risk becomes unbearable to the merchant and producer. So a special class of people are needed who have a good knowledge of the world wide conditions of the commodity traded, as well as knowledge about other factors related to the newly changing world of commercial revolution. The need for the existence of this class was also important as the element of speculative judgment and risks became more important and distinguishable; this in turn gave a greater burden for the merchant to carry. Hence, the emergence of a distinct body as a risk taker was appropriate and was important in order to relieve the merchants of the speculative elements of their business (Emery, 1968, pp. 104-109).

The other function of speculation is its role in stabilizing, or more accurately moderating, the range of price fluctuations (Kaldor, 1939, p. 1). The speculators will step in as buyers when the supplies of commodity are in abundance, hence moderating the price fall. While in the instance of demand over supply, they will act as sellers and plug the commodity into the market from their storage. This will accordingly prevent the price rise from becoming too high. This also implies that speculators in certain instances would help to even out the consumption of the crop between harvest times and provide ample amounts between the seasons. In other words, the work done by the speculator contributes towards a smooth distribution of supplies as relative to changing demand over time (Yamey, 1966, p. 207).

In addition to the above, the role of stabilizing price fluctuation is not confined alone between two different time limits, but it also stabilizes price differences occurring simultaneously in two different markets. The action of professional speculators, described by Samuelson as those who patiently keep their eye on the market (Samuelson, 1958, p. 423), buy at the cheaper market and then sell it at the higher market to make profits for themselves. Consequently, this could stabilize the price between the two distant markets.

This activity will at the same time contribute to the pattern of consumption of the product from places where they have a lower utility to places where utility is higher (Kaldor, 1939, p. 1). Through the existence of middlemen, (the stockists, who buy products in large amounts from the producers at the time of 'over production' or whenever the goods are available abundantly. This kind of middleman buys things for the purpose of selling them later, whether to the small retailers or by himself to sell directly to buyers acting as speculators, who dare to take over any risks that are usually faced by the actual producers, the price of the product is to some extent stabilized. This is especially obvious in the agricultural sector.

Regardless of the outcome of the discussion about the influence of profitable or even unprofitable speculation on price stability (Friedmen, 1953, p. 175; Baumol, 1957, p. 263; Aliber, 1964, pp. 607-609), and of its level of influence, whether it fully or partially affects the price stability, it is universally agreed that speculation to a 
certain extent contributes towards price stability. Hence, the conclusion arrived at by Kaldor that speculation does simultaneously exert a price stabilization as well as a destabilization influence, is a way of reconciliation between those two different opinions on the subject matter (Kaldor, 1939, p. 10).

As pointed out by Kaldor, speculative activity could also have an effect on income stability, and synonymously could increase investment which indicates an improvement in the general level of economic activity. However, this is so in the case of 'income-goods' as termed by him and not in the case of 'capital-goods'. The larger the amount spent on 'income-goods', the lesser the amount left for other goods which are here referred to as speculative stock, since the money spent is taken from the total income received. Hence, the amount left for other purposes is being reduced due to this acquisition. This argument is put forward however, with the assumption that the level of income is stagnant or unchanged and the entire amount of an individual's income is thoroughly spent (Kaldor, 1939, pp. 17-24).

Another important function of speculation which is stated by economists is its role in making the market work and continuing function. It is a clear fact that the existence of speculators making speculative judgments leads the market to continue operating. Regardless of whether the speculator is making profit or incurring losses in their market comprehension of the price movement, their active participation in the business liquidates the market. It is not surprising therefore, that some economists believe that without the presence of the speculator, future markets could not function (Teweles et al., 1965, p. 4).

These are some of the functions carried out by speculators in their capacity of making speculative judgments in the world of business. Although it seems to us that speculation has been playing an important function in economics, it does not imply that speculation and the speculators will continue doing favors for the economy at all times and in all conditions. In fact Rix made an important observation concerning the influence of speculation and speculators on the stock exchange, when he said, "investors are much more useful to speculators than speculators are to investors, and the stock exchange would not necessarily be any less effective if there was no speculation at all" (Rix, 1965, p. 212).

The above statement is something not to be taken lightly, as speculation has sometimes sent the economic condition of a country into a chaotic, unstable and even a volatile down situation. Once this happens, it can take a very long time for the economy to be restored, due to the fact that public confidence in that country as well as international confidence would be affected.

\section{The Negative Consequence of Speculation}

The contribution of speculative transaction to the financial crisis of a country as well as the economics of the world is something that should not be forgotten. There have been many financial crises that have taken place throughout the history of financial economics. The history of the financial crises of Western Europe goes back as far as the 16th century in 1522 and 1557 (Kindleberger, 1984, p. 13). However, as the financial crises that took place before the 18th century had a lack of monetary features, which were only developed after the development of the banking system in the 18th century, the discussion on speculation and its relation with financial crashes usually starts from the 18th century (Kindleberger, 1978, p. 6).

There were many financial crises which took place between the 18th century and the 20th century. Amidst the early 19th century (1825) until the early 20th century (the World Great Depression-1929), there were at least 13 financial crises (The New Encyclopædia Britannica, 1991, p. 537). Some of the crises did not adversely affect the economy of that particular country. However, undeniably, some of the financial crises had tremendous economic consequences, not only for the particular country involved but, unfortunately, also affected the economics of the world as a whole. This shows how remarkably strong it was and how it was due to the influence of speculative transactions in the financial markets.

The contribution of speculation in the history of financial crises and world depression is commonly accepted and it can be traced back to the early 17th century (Kindleberger, 1978, p. 4). The wilderness of speculation in any financial crisis usually develops in two different stages (Kindleberger, 1978, p. 30). Firstly, people from all walks of life make a real and sober investment their surplus income. At this stage, they are investing rationally (Blanchard et al., 1993). Secondly, when the fever of speculation starts, the rational investors will turn their back on the principles of investment that they hold, and are transformed from being sober and rational investors into people full of imagination and irrationality. If this craziness overpowers their sanity, they will start to compromise their principals and morals and accumulate profit through capital gain. Business gain, dividend or interest would no longer be their prime consideration. 
In the above situation they would no longer be open to rational advice. Unfortunately, this mental and emotional instability does not only affect the speculator but also the 'people in power' who are also carried away by the immediate economic prosperity. People in power here not only refer to the political leaders or the actual leader of a country, but the term also implies more specifically those who take charge of economic institutions. At this time they ignore advice from economists and close eyes and minds to the possibility of an economic crash (Yass, 1970, p. 21).

Regarding the above, obviously, when the fever of speculation starts and infuses the attitudes of a nation, everybody rushes to the market, buying whatever is left. Regardless of whether they possess good skills of analysis and forecasting abilities, or whether they purely gamble their available money, they continue as long as profit is still pouring in. This attractive economic attainment encourages many more 'alien' participants; (those who do not know enough about the business of stock exchange), to enjoy the 'sudden economic prosperity.' However, when panic comes and is followed by the crash, the chaos of the market becomes on many occasions, uncontrollable. For example, in the New York Stock Exchange crashes on 'Black Thursday', almost 13 million shares were transacted in this single day, and this was followed by a second crash, namely 'Black Tuesday' during which the shares transacted were more than 16 million. More disastrously, there were some stocks that became virtually unsaleable at any price (Rees, 1970, p. 48; Kindleberger, 1977, p. 118).

Regrettably, those who suffered the greatest financial loss of the Wall Street crashes were incurred by small investors and unprofessional speculators who had been allured into participating in the market without adequate resources to cover their marginal losses and with inadequate means for acquiring up-to-date information about the progression of the market (Rees, 1970, p. 50-51). Chapra in his writings contended that no 'insider' knowledge, no forecasting capability and being carried away by rumors and impulses (Chapra, 1985, p. 97), were among the reasons for the downfall of small investors and unprofessional speculators.

\section{Financial Crises and Speculation in History}

The above two manias, although having the lack of monetary characteristics which did not appear before the introduction of the banking system in the early 18th century, the crises did give adequate evidence regarding the contribution of speculative transactions. In both cases, the word mania is purposely used to show the craziness of the society on speculative excess. Revulsion from these situations leads to panic, crash, and crisis (Kindleberger, 1978, p. 4). This shows and implies directly the contribution of speculation in the economic crises. Furthermore, prior to the crisis, all kinds of sophisticated transactions which actually create a conducive environment for speculative activity are being introduced, such as short selling, puts and calls, future trading and option (Kindleberger, 1984, p. 215).

The development of the Mississippi Bubble in Paris in 1719-20 is said to have originated from the same and common cause that is speculative euphoria (Kindleberger, 1985, p. 226). The crisis was followed by the South Sea Bubble in London in 1720. Both crises are considered to be among the significant financial crises that occurred. In describing the occasion shortly before the crisis occurred, Warren wrote,

"In a very short space of time the fever for speculation infused itself into the blood of the whole nation ... Everybody who had money to invest was interested in this gigantic gamble ... The period was one of mad speculation" (Warren, 1906, p. 178).

The tragedy of the South Sea Bubble as demonstrated by Walpole is merely due to gambling, and through this it made people rich in a very short time. However, it was a temporary success based purely on the price movement of the South Sea Company's shares, which moved from a lower level to the highest ever, shortly before the crash. Billions of pounds of capital that belonged to the society were taken away wastefully into the hands of some speculators. Suicide was a daily occurrence during the time of this British national disaster.

In Britain, after the South Sea Bubble that swept away millions of the society's capital, the other crisis closely related to the mania of transaction of a speculative nature, was the Railway Mania in 1847. The railway development in Britain as well as abroad attracted many real investors to rationally participate in the project between 1830-35 through investing their capital. Definitely, it was not one of the bubbles in the first stages of its development. The investment of the British alone in French railroads at the time amounted to a staggering figure of 25 million pounds (Kindleberger, 1984, p. 221).

The atmosphere of sober and rational investment did not survive very long. As correctly pointed out by Kindleberger previously, the second stage will always appear in the development of any mania. After 1835, as the prosperity of the railroads escalated, everyone from society who was 'taken by storm' participated in buying railway shares which consequently turned the share market into an atmosphere of financial insanity. As 
illustrated by Matthews (Kindleberger, 1978, p. 31), the mania attracted individual from all walks of life including ladies, clergymen, widows, spinsters, retired navalmen, army officers, magistrates, charitable institutions, theologians and orphans.

One important point that is worth mentioning here is that the price of capital during the time of 1844-45 was very cheap. This eventually led to the hyperbolizing of the existing market of the time, which had already been saturated. As the price of capital only cost borrowers 2.5 percent which was affordable by everyone, it provided a good chance for every individual to participate in the game of speculative transaction. Consequently, the railway boom attained its zenith in 1845 and unexpectedly all of sudden, it plunged rapidly to the bottom (Morgan, 1965, p. 147). In the words of Warren;

"England was in the hands of the surveyor, and the boom began in real earnest. As usual, everybody was to become immensely rich and as usual, most people were again bitterly disappointed...Hope, after a very little while, drives out of the memory of human beings the nightmare of disaster; so in an astonishingly short space of time, they are gambling again" (Warren, 1906, pp. 33-34).

However, when the disaster struck, everybody ran to the banks to have money on credit and the banks were not able to fulfill the sudden demand for money from everybody. The situation in the banks was extremely chaotic and some of the banks even closed their doors, while The Bank of England at first refused to advance against securities (Warren, 1906, pp. 35-36; Morgan, 1965, pp. 147-153). As usual, when the chaotic situation prevailed, it indicated that things were on the edge of crisis.

In the above few examples of the past financial crises, it is clear that the crises always advanced in two stages, as stated in the early part of this discussion. In fact, the advancement of these two stages in speculative related financial crises was obvious and indisputable. In the following, attention will be focused on the New York Stock Exchange crashes which consequently led to the World Great Depression of 1930s, which gained control of economic prosperity in the early 1920 s.

\section{Speculation and the New York Stock Exchange Crash}

The World Great Depression judging by almost all economic indicators was the worst and the most severe of all economic depressions and crises (Fearon, 1979, p. 9). Moreover, it was not only the worst crisis, but also among the longest depression, which lasted from 1929 to 1939. Meanwhile, the affected countries were not only restricted to the manufacturing countries, the center of the depression, but the crisis spread all over the world, including those countries whose income was mainly based on natural resources and agricultural products. Indeed the above tragic financial crisis was followed by an economic depression that swept the whole of Europe was devastating. In other words, the economic depression that had been experienced by the whole world was very severe, and its severity was incomparable to any other economic disaster that occurred before or after the World Great Depression.

After the First World War, the U.S. emerged as a new economic power of the world. The prosperity that was achieved by the U.S. was staggering and had not been achieved by any nation or country before. Its economic stability was apparent, profits were very high, the cost of production was immutable, the capacity for industry was in surplus, the level of wages was soaring and stable, and the savings were plentiful. The economic prosperity of the U.S. was said to depend on two major factors that were prevailing, i.e. mass production and hire purchase, which enabled Americans to live prosperously. This is so because mass production reduces the cost and increases the income and hence, more people are capable of owning more and more products, especially with the introduction of hire purchase selling. Consequently, workers were able to own cars and other household items of luxury.

It is worth summing up the above prosperity achieved, by quoting a few speeches delivered by politicians in their election campaign of 1928. The Republican slogan in the election campaign was "a car in every garage and a chicken in every pot" (Yass, 1970, p. 12), which shows that the life styles of the Americans were no longer struggling to attain basic needs or even comfortable needs, but rather needs of having a luxurious lifestyle. While Hoover, a candidate for the Presidential post was quoted as saying,

"We in America today are nearer to the final triumph over poverty than ever before in the history of any land. The poorhouse is vanishing from among us...By our energies in invention and enterprise we have raised our per capita productivity to levels never hitherto known in the world" (Yass, 1970, p. 11).

Actually, the New York Stock Exchange that had been established on July 17th, 1792 had developed as the strongest and most predominant financial center of that time (Rees, 1970, p. 11). The New York Stock Exchange became more important in the second quarter of 1928 which led to the cut-off of long term lending by the U.S. to 
Europe and other comparatively poor countries. This step was taken to increase financial availability to finance the sudden boom of the New York Stock Exchange, more precisely to finance the speculative activity of the market.

The above situation was correctly pointed out by an economist (Kindleberger, 1977, pp. 108-109). He states that the danger that existed in the market was neither embodied by the large amount of daily transaction of shares, nor by the level and frequent change of share prices, but it was mainly due to the precarious credit mechanism which supported and fed the speculative activity. The loans given to brokers for their speculative activities increased every year from only 2.1 billion dollars in 1926 to nearly 7 billion dollars immediately before the crash, and almost 3 billion of it came directly from the banks (Rees, 1970, pp. 25-26). Hence, the collapse of the New York Stock Exchange was being invited (James, 2010).

The New York Stock Exchange boom was an exceptional period in the history of financial advancement. Although the incredulous achievement of the New York Stock Exchange has been said to be a closely related factor of the economic strength and financial system of the U.S., the significant factor that led to the 'immediate economic prosperity' of the New York Stock Exchange was actually speculation (Rees, 1970, p. 16). This drastic affluence was incomparable with the previously discussed, South Sea Bubble, since the attractive game of speculative transaction infused the mass movement of American people to participate in the game. In the words of Baruch: "a classic example of the madness of crowds" (Rees, 1970, pp. 14-16).

In the above situation it would be more illustrating to seek explanation about the madness of the masses through the movement and participation of the crowds in the game of speculative transactions of the New York Stock Exchange. As the irrational element cropped up and contaminated the transactions of the New York Stock Exchange, the market lost its grip on reality and speculative mania began to get the upper hand over the usual rationality of society. Hence, the downfall of the market was already predetermined.

When speculative mania overshadowed the previously rational transaction of the market, everybody, as had been demonstrated in previous crashes, would rush to catch the market in order to get rich quickly. Americans, regardless of their class in society, held stock on margin during the spectacular summer of 1929. More than a million people speculated in the market, especially on stock trading on margin (Rees, 1970, p. 25). Rees, in illustrating the number of participants of stock trading on margin said, "There seems to be no way of computing" (Yass, 1970, p. 21). It does not matter whether they analyzed or not, they miraculously won, so long as they got their surplus money into the market.

In the above fabulous period of the New York Stock Exchange, no one lost what the winners gained. Everybody in the market got his/her share of the instant prosperity. However, no one seemed to be aware that the instant abundance of profit that they were calculating, and that the prosperity that they were undergoing was all restricted to and attributed to paper terms only. If everyone intended to liquidate those profits into cash, they would have been frustratedly evanesced (Samuelson, 1958, p. 426). In this situation of speculative mania, the bubble had to burst eventually (Rappoport \& White, 1993).

The panic situation and the crash of the New York Stock Exchange had taken place on two different days, which were known as 'Black Thursday' and 'Black Tuesday', towards the end of October of 1929 (Kindleberger, 1984, p. 336), though the real starting point for the decline of the stock prices was earlier in the month (Studness, 1968). The value of shares started devaluate steadily until the 24th of October 1929, which they called 'Black Thursday'. This is when the New York Stock Exchange crash first occurred and everyone was unfavorably, caught out (Rappoport \& White, 1993).

Many efforts had been undertaken by leading bankers, financiers and the Federal Reserve Bank of New York to stop the further decline of the stock prices. Even the Federal Reserve Bank was violating its standing orders from the Open-Market Committee (Kindleberger, 1977, pp. 118-119) through a 'big buy' of securities, far beyond the prescribed limits, which was 25 million dollars a week. The Federal Reserve Bank spent 160 million dollars to buy securities during the first buying in the last week of October and another purchase worth 370 million dollars in the following month.

In spite of every step that had been executed, the panic situation did not cease and the share price downfall continued undesirably. On the 26th of October, president Hoover made assurances published in the New York Herald Tribune, saying, "the stock market held up like a stone wall yesterday." This statement of assurance was followed and supported by the press which commented that "there was nothing in the country's fundamental business conditions to cause uneasiness." However, the price of shares continued to fall during the following few days. 
Accordingly, as the situation worsened, the second crash of the New York Stock Exchange, which was worse than the first, eventuated unrestrainedly on the 29th, October 1929. This crash was more famously known as 'Black Tuesday'. In the first crash the 'Black Thursday' the amount of shares transacted during that particular day was almost 13 million shares, a record by then. However the second crash of 'Black Tuesday' saw a record of more than 16 million shares transacted (Kindleberger, 1977, p. 118). The volume transacted reflected uncontrollable panic and chaos had taken place in the market. After the tragedy of 'Black Tuesday', the market continued to fall until it reached the lowest in history, in 1932 (Samuelson, 1958, p. 427). During this tumultuous period, in the words of Samuelson,

"Billions of dollars of securities values were wiped out every month, taking with them not only the capital of gamblers out of speculative gains, but also the widows' mite supposedly invested for steady income. A 'blue chip' stock like United States Steel fell from a high of 261 in 1929 to a low of 21 in 1932, while less respectable securities dropped off the Board completely" (Samuelson, 1958, p. 427).

The economy of the U.S. during this time passed through a very real horror of a financial crisis and crash. It affected not only the speculators and gamblers, but senselessly it also troubled millions of genuine small investors in the years between 1929-33 (Coakley \& Harris, 1983, p. 69).

\section{Speculation Precedes the Crash}

The above discussion especially on the edge of the New York Stock Exchange crash, undoubtedly shows everyone the direct role played by speculation and speculative transactions in the market. Hence, the contribution of the game of speculative transaction in the collapse of the market, was beyond doubt of prime importance. The irrational element and the infection of speculative mania was rampant at the time of the boom between 1925-28, and in the first three quarters of the year 1929. When speculative mania overpowered the American's sanity, they were forgetting the collapse of Florida's land booms that had taken place at almost the same time, between 1926-29, which had seen the disappearance of 31 banks in the year of 1928, and 57 in 1929 in Florida (Rees, 1970, pp. 13-25).

During the roaring twenties, the income in the U.S. soared, which subsequently increased the ability of citizen spending. Most of the spending was poured into the stock market and regrettably, was based on the gamble relating to speculative transactions. Some of the people purely participated in the market without any knowledge or skill in forecasting. Hence, they were participating in the market as gamblers did in any casino based purely on gamble and luck. Furthermore, their participation was primarily motivated by that short period of economic prosperity whereby anybody could participate and could win easily. Consequently, the dangers of speculative excesses that ruined their predecessors was again weaving the crash (McGrattan \& Prescott, 2004).

Unfortunately, those who had knowledge of the previous speculative manias did not appreciate it, as they unduly participated in the game of speculative transaction with two beliefs in their hearts; firstly, that profit was certain to be acquired from the market and secondly, that the previous incidents of financial crashes due to speculative excessiveness were inapplicable to the U.S. (Yass, 1970, p. 14). This wild and unrestrained optimism among the public, as well as among the political leaders of the country encouraged more enthusiasts into the market (Yass, 1970, pp. 13-25). Even after 'Black Thursday' of the 24th October 1929, the first crash of the New York Stock Exchange, President Hoover did not acknowledge the situation, instead he gave assurances to the public that the country's economics and business remained strong and nothing should trigger uneasiness among the public (Yass, 1970, p. 25).

As mentioned before, stock trading on margin was so rampant during the boom period of the New York Stock Exchange. Trading on margin allowed the speculators to hold securities with only part of the payment paid and the rest considered as a margin account which was handled by the brokers. If the price of shares went up, the speculators who traded on margin would get a large profit and vice versa. If the share prices went down, they would top up their loss capital, which was also a larger amount compared to those who did not sell on margin. This type of sale is greatly speculative in nature, as the reason for indulging in this kind of trading is for larger profit by speculating on an increase in share prices. Moreover, margin selling especially encourages speculators with small capital to speculate and buy shares far beyond their capability, through the help of brokers.

Ironically, in circumstances where the price of shares decreases continuously, speculators are forced to sell out their margin stock holding. The reason for this is due to them no longer being able to cover their margin account on the depreciating value of their securities in the hands of the brokers. This was the actual event that took place during the crash of the New York Stock Exchange on 'Black Thursday' and 'Black Tuesday' in October 1929. The failure to cover their margin accounts caused the brokers to sell the securities at whatever price that was available in the market. These circumstances caused the market to crumble down even further. Since the real 
investors lost one-third of their capital at the end of 1929 which then fell further down to one-sixth by 1932 (Samuelson, 1958, p. 427), what would be the loss of speculators who indulged in selling stock margin? This is in fact the undesirable consequence which had to be faced in the game of speculative transaction of selling stock on margin.

One important factor that initiated and fuelled the game of speculative transaction which led to the market crash was the excessively easy availability of loans for speculative purposes. The danger inherent in this credit mechanism was only understood by a few bankers and financiers. They believed that the brokers' loans, that were feeding the game of speculative transaction of the market, should have been curbed. A suggestion was made by the President of the Federal Reserve Bank of New York, to increase the discount rate from 5 to 6 per cent in order to slow the flow of loans into the speculative market. This suggestion was rejected by the Board of Governors. Finally it was permitted on 9th August 1929 when the crash was already looming on the edge (Kindleberger, 1977, pp. 109-113).

Unfortunately, some of the bankers in New York were directly involved in giving loans to the customers. These steps actually fuelled the speculative transaction game that was already burning in the market. Many more 'aliens' from the public participated in the market, as there was easy availability of capital funds from the bank. This was the danger of easy availability of credit for financing speculative activity in this particular period, and in the other previous financial crises. Market attractiveness and easy borrowing brought to the market participants who never ordinarily entered the market, and who did not really understand the existence of risks in the market they were enthusiastically seizing (Rix, 1965, p. 216).

However, the real fact was that, the bankers were unable to resist the available profit from the market which was offered to them. Being tempted, they borrowed from the Federal Reserve Bank at 5 per cent and passed it to the brokers at 10-12 per cent with an easy profit in hand (Rees, 1970, pp. 24-25). In the instance of the bull market, the bankers were easily acquiring their share of the profit due to the insanity of the market at 5 to 7 per cent. Understandably therefore, the brokers' loans kept increasing, starting from the early 1920s, and by October 1929, shortly before the crash, the total amount of brokers' loans was nearly 7 billion dollars (Rees, 1970, p. 24). As stated by Born, in the year 1929, the proportion of brokers' loans from the U.S. banks was more than 35 per cent (Born, 1983, p. 250). This evidence shows how the purchase of securities during the boom years had played a major role in the credit system of the U.S. economy, even though the demand for it had turned into a game of speculative transaction.

One point worth mentioning here, is that there were also large amounts of brokers' loans, taken from the U.S. firms as well as from other countries which were feeding the game of speculative transaction. These loans contributed to the increasing number of participants in the already 'burning' market. The easy availability of funds to the brokers meant that there were chances for them to fully utilize the given facility in order to maximize their profit. Hence, they did not only participate in the bull market but also in the bear market. Clearly, speculative mania had the upper hand over the market through the availability of brokers' loans. In the words of Rees: "In normal time this was simply a matter of convenience, but during 1928-29 the enormous rise in brokers' loans was one of the best indications of the growth of speculation" (Rees, 1970, p. 24).

The above discussions on the crash of the New York Stock Exchange disclose the role played by speculation and the game of speculative transaction. The easy credit policy that was prevailing during the time directed the bull market into unrestrained speculation. Furthermore, over-optimistic about the continuation of the bull market and the U.S prosperity, not only among individuals in society but also among the U.S. leaders and bankers, led to the exaggeration of speculative transactions in the New York Stock Exchange. As correctly pointed out by Born, excessive speculation in securities is among the major factors in the collapse of the New York Stock Market and consequently, the beginning of the World Great Depression (Born, 1983, p. 256).

\section{Conclusion}

To conclude, the prominent role played by speculation in the financial crashes and crises is manifested. This was more clearly evident in the crash of the New York Stock Exchange, where a detailed account of the role played by speculation and speculative transaction has been illustrated. Although there were many other financial crashes that occurred before and after the crash of the New York Stock Exchange, the discussion of the U.S. tragedy is taken to represents the others. It represents a classic example of speculative excessiveness which was stimulated by the over-optimism of the American leaders and bankers and the rampant and greed participation of the public. Apparently, the crash of the New York Stock Exchange was the starting point of the worst economic tragedy, the World Great Depression. 
Convincingly, the role of speculation is prominent in the past financial crises of the world, and probably will also be in the future. As far as the question of regulating speculation is concerned, there were steps taken to ensure that speculative activity would not be allowed to go beyond a certain limit. At the end of the 19th century, several bills were implemented in the U.S., with the purpose of suppressing and clamping down on speculation (Emery, 1968, p. 7). Whilst in Germany, an advanced step was taken to curb speculation through establishing an Imperial Commission to investigate all aspects related to speculation. Consequently, restrictive legislation was passed in 1896 which was to be implemented one year later, January 1897 (Emery, 1968, p. 8).

After the crash of the New York Stock Exchange of the U.S. which economists believed to be 'the home of the World Great Depression in the 1930s', the problem of speculation and speculative transaction in the stock market emerged as a sensational topic of discussion. To show the seriousness of the problem in the operation of a stock market, there were numerous regulations designed in the U.S. after the crash. Unfortunately, the law established did not curb the problem totally but only ensured that speculative activity was carried out more conscientiously and in a law abiding way. Those are the negative effects consequences of speculation on an economy. Whenever it lays a finger on the market, its effect will be felt intensely, and to recover from such turmoil will take a long time. Hence, as far as the question of speculation is concerned, the tragedy of 'Black Thursday' and 'Black Tuesday' of the New York Stock Exchange crash served as a turning point for the monitoring of speculative excessiveness.

\section{References}

Aliber, R. Z. (1964). Speculation and Price Stability; Once Again. Journal of Political Economy, 72.

Barro, R. J. (1990). The Stock Market and Investment. The Review of Financial Studies, 3(1), 115-131. http://dx.doi.org/10.2307/2961961

Baumol, W. J. (1957). Speculation, Profitability and Stability. Review of Economics and Statistics, 39.

Blanchard, O., Rhee, C., \& Summers, L. (1993). The Stock Market, Profit, and Investment. The Quarterly Journal of Economics, 108(1), 115-136. http://dx.doi.org/10.2307/2118497

Born, K. E. (1983). International Banking in the 19th and 20th Centuries. Warwickshire: Berg Publishers Ltd.

Chapra, M. U. (1985). Towards a Just Monetary System. Leicester: The Islamic Foundation.

Coakley, J., \& Harris, L. (1983). The City of Capital. Oxford: Basil Blackwell Publisher Ltd.

Emery, H. C. (1968). Speculation on the Stock and Produces Exchanges of the United States. New York: Ams Press.

Fearon, P. (1979). The Origins and Nature of the Great Slump 1929-32. London: The Macmillan Press Ltd.

Friedmen, M. (1953). Essays in Positive Economics. Chicago.

Galbraith, J. L. (1969). The Great Crash 1929. Middlesex: Peguin Books Ltd.

Goetz, P. W., et al. (Eds.). (1991). The New Encyclopcedia Britannica. Chicago. Encyclopædia Britannica Inc. "Ceausescu, Nicolaei" in Micropædia Vol. 3.

Hanson, J. L. (1977). A Dictionary of Economics and Commerce (5th ed.). Playmouth, Macdonald and Sons.

James, H. (2010). 1929: The New York Stock Market Crash. Representations, 110(1), 129-144. http://dx.doi.org/10.1525/rep.2010.110.1.129

Kaldor, N. (1939). Speculation and Economic Stability. The Review of Economic Studies, 7.

Kindleberger, C. P. (1977). The World in Depression 1929-39. London: Allen Lane Penguin Books Ltd.

Kindleberger, C. P. (1978). Manias, Panics, and Crashes; A History of Financial Crises. London: The Macmillan Press Ltd.

Kindleberger, C. P. (1984). A Financial History of Western Europe. London: George Allen \& Unwin.

Kindleberger, C. P. (1985). Keynesianism vs. Monetarism and Other Essays in Financial Histroy. London: George Allen \& Unwin.

McGrattan, E. R., \& Prescott, E. C. (2004). The 1929 Stock Market: Irving Fisher Was Right. International Economic Review, 45(4), 991-1009. http://dx.doi.org/10.2307/3663617

Morgan, E. V. (1965). The Theory and Practice of Central Banking 1797-1913 (2nd ed.). London: Frank Cass \& Co. Ltd. 
Ransom, R. L. (1982). Great Depression. Encyclopedia of Economics (Ed. by Douglas Greenwald). New York. McGraw-Hill Inc.

Rappoport, P., \& White, E. N. (1993). Was There a Bubble in the 1929 Stock Market? The Journal of Economic History, 53(3), 549-574. http://dx.doi.org/10.2307/2122405.

Rees, G. (1970). The Great Slump: Capitalism in Crisis 1929-33. London: Weidenfeld and Nicolson.

Rix, M. S. (1965). Stock Market Economics. London: Sir Isaac Pitman and Sons Ltd.

Samuelson, P. A. (1958). Economics; An Introductory Analysis. New York: McGraw-Hill Book Company, Inc.

Soros, G. (1994).The Alchemy of Finance. New York: John Wiley \& Sons Inc.

Studness, C. M. (1968). New York Stock Exchange Trading in Perspective. Financial Analysts Journal, 24(6), 26-36. http://dx.doi.org/10.2307/4470424

Teweles, R. T., Harlow, C. V., \& Stone, H. L. (1965). The Commodity Futures Game. New York, McGraw Hill.

Warren, H. (1906). The Story of the Bank of England (2nd ed.). London: R.A. Everett \& Sons.

Yamey, B. S. (1966). Speculation and Price Stability: A Note. Journal of Political Economy, 74.

Yass, M. (1970). The Great Depression. London: Wayland Publishers.

\section{Copyrights}

Copyright for this article is retained by the author(s), with first publication rights granted to the journal.

This is an open-access article distributed under the terms and conditions of the Creative Commons Attribution license (http://creativecommons.org/licenses/by/3.0/). 